\title{
Lesbian Brides: Post-Queer Popular Culture
}

Dr Kate McNicholas Smith, Lancaster University

Department of Sociology

Bowland North

Lancaster University

Lancaster LA1 4YN

k.mcnicholassmith1@lancaster.ac.uk

Professor Imogen Tyler, Lancaster University

Department of Sociology

Bowland North

Lancaster University

Lancaster LA1 4YN

i.tyler@lancaster.ac.uk 


\begin{abstract}
The last decade has witnessed a proliferation of lesbian representations in European and North American popular culture, particularly within television drama and broader celebrity culture. The abundance of 'positive' and 'ordinary' representations of lesbians is widely celebrated as signifying progress in queer struggles for social equality. Yet, as this article details, the terms of the visibility extended to lesbians within popular culture often affirms ideals of hetero-patriarchal, white femininity. Focusing on the visual and narrative registers within which lesbian romances are mediated within television drama, this article examines the emergence of what we describe as 'the lesbian normal'. Tracking the ways in which the lesbian normal is anchored in a longer history of "the normal gay" (Warner 2000), it argues that the lesbian normal is indicative of the emergence of a broader post-feminist and post-queer popular culture, in which feminist and queer struggles are imagined as completed and belonging to the past. Post-queer popular culture is depoliticising in its effects, diminishing the critical potential of feminist and queer politics, and silencing the actually existing conditions of inequality, prejudice and stigma that continue to shape lesbian lives.
\end{abstract}

Keywords: Lesbian, Television, Queer, Post-feminist, Romance, Soap-Opera 


\section{Lesbian Brides: Post-Queer Popular Culture}

Increasingly.... to have dignity gay people must be seen as normal (Michael Warner 2000, 52)

I don't support gay marriage despite being a Conservative. I support gay marriage because I'm a Conservative (David Cameron, 2011).

These days, Coronation Street is the new Canal Street ${ }^{\mathrm{i}}$, as yet another lesbian rocks up on those infamous cobbles this autumn (Kaite Welsh, 2015)

Figure 1. Sophie \& Sian's Wedding Day (Coronation Street, December 29 2011, reproduced with permission)

\section{Bridal Fantasies}

On December 29, 2011, British soap opera Coronation Street (Granada/ITV, 1960-present) aired Episode 7768, one in a series of much anticipated Christmas episodes to an audience of 10 million viewers. This wedding special featured two young brides, Sophie Webster (Brooke Vincent) and Sian Powers (Sacha Parkinson) (figure 1). Framed in a traditional church setting, wearing identical virginal white wedding dresses with white flowers in bouquets and in their softly waved hair, these two brides embody what Vicky Ball describes as a post-feminist "re-traditionalization" of femininity on television (Ball 2012). Indeed, at first glance, we seem to be witnessing a display of the "traditional femininities that post-feminist popular culture covets" (Winch 2012, 72). Coronation Street's brides evoke the romance narrative of "sister-brides", exemplified by the double-wedding that concludes the televised adaption of Jane Austen's Pride and

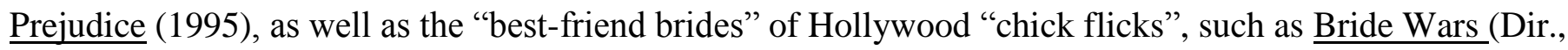
Gary Winick, 2009) (Rosalind Gill and Elena Herdieckerhoff 2006, 494). However, while the Coronation

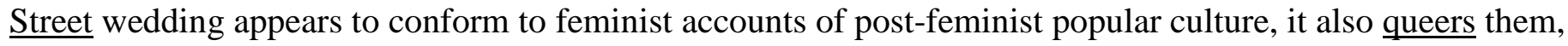
since the two brides standing at the altar are to be married, not to waiting grooms, but to one another. In a 
storyline first introduced in April 2010, Brooke Vincent and Sacha Parkinson portrayed Coronation Street's first lesbian relationship. The December 29, 2011 episode promised the spectacle of their wedding, the first 'same-sex' marriage on a British television soap opera. ${ }^{\text {ii }}$ However, joining a large archive of soap-opera wedding day disasters, the Coronation Street nuptials ended in disaster, with one bride (Sophie) having lastminute doubts and the other (Sian) fleeing the altar. Nevertheless, the depiction of a lesbian white church wedding on Britain's longest-running television soap opera, a drama that ostensibly depicts "ordinary" working-class lives in Northern England, marks a shift in socio-sexual representation that would have been unimaginable just a decade previously.

\section{Introduction: The Lesbian Normal}

Judith Butler asks "Who or what is it that is 'out', made manifest and fully disclosed, when and if I reveal myself as a lesbian" (Judith Butler 1993, 309). We are interested in exploring this question, through a consideration of the ways in which lesbianism has been 'brought out' and is being actively crafted within mainstream popular culture. The aim of this article is to make feminist sense of the lesbian normal that is emerging through this process.

The last decade has witnessed a proliferation of lesbian representations in European and North American popular culture, particularly within television drama and broader "celebrity culture". As Daniel Marshall notes, "television across many Anglophone markets (especially those of North America, the United Kingdom, and Australia) seems comparatively full of self-declared gay and lesbian characters", a market in sexual diversity that is rapidly expanding to include "a wider range of avowedly queer subjects" (Daniel Marshall 2016, 85). The proliferation of 'positive' and 'ordinary', as opposed to deviant or pathological, mainstream representations of lesbian romance is significant. ${ }^{\mathrm{iii}}$ From British soap-operas such as Coronation

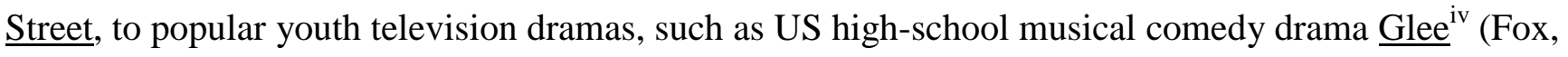
2009-2015), and the edgier adult-orientated content of Orange is the New Black (Netflix 2013-), Sense8 (Netflix 2015) and Transparent (2014-) televisual lesbianism is widely celebrated for extending the visibility 
of non-heterosexual sexualities. As performance studies scholar Lori Montalbano-Phelps typically phrases it, queer television has "the power... to help define a generation of acceptance" (Lori Montalbano-Phelps 2013, 55). There is an assumption in these kinds of statements that visibility signifies progress in queer political struggles for social equality, but what kinds of queer futures are imagined in this progress narrative? As we will detail, the very terms of the visibility extended to lesbians within mainstream television drama often affirm ideals of hetero-patriarchal, white, middle class femininity. In other words, the new lesbians on television display the "traditional femininities that post-feminist popular culture covets" (Alison Winch 2012, 72).

In "Postfeminism and Popular Culture" (2004) Angela McRobbie argues that the sexual politics of the contemporary period is characterised by a "double entanglement" of "neo-conservative values in relation to gender, sexuality and family life $[. .$.$] and processes of liberalisation in regard to choice and diversity in$ domestic, sexual and kinship relations" (Angela McRobbie 2004, 255-256). Underpinning this "entanglement" of conservativism and sexual liberalism is a "repudiation" of feminist politics (McRobbie 2004, 256). One consequence is that "pre-feminist ideals", such as the white wedding, are seductively "repackaged as post-feminist freedoms in ways that do nothing to question normative heterosexual femininity" (Gill and Herdieckerhoff 2006, 499). One of the powerful contradictions of post-feminist media culture is the way in which it combines feminist "discourse[s] of freedom, liberation, and pleasure-seeking" with “the equally powerful suggestion that married heterosexual monogamy more truly captures women's real desires" (Gill and Herdieckerhoff 2006, 500).

Writing a decade after these influential accounts of the entanglement of feminist and anti-feminist ideas and values within post-feminist popular culture, we seek to extend this post-feminist analysis through an examination of representations of lesbian romance on television. ${ }^{\mathrm{v}}$ This article centres on the restricted visual and narrative registers within which lesbian figures and relationships are mediated within everyday televisual cultures, offering a critical interrogation of what we term the lesbian normal, and the terms of the 
inclusion it mediates. Employing the Coronation Street lesbian wedding as a guide, this article considers what kinds of feminist sense we can make of the appearance of lesbian brides on mainstream television. Is this lesbian white wedding an expression of growing sexual democracy, or a post-feminist announcement that there is to be "no escape" from what Lena Dunham describes as the tyranny of "the bride in the head"? (Lena Dunham 2012). Are we stuck with the hegemony of $21^{\text {st }}$ Century "white bridal culture" (Chrys Ingraham 1999)? Is lesbianism now sutured to femininity in ways that allow (some) girls and women to become respectable lesbians on the condition they 'do gender' in ways that conform to heteronormative social rules?

The first part of the article considers the Coronation Street lesbian wedding in the context of both the working-class history of this soap, and the introduction of legal marriage equality in the UK. The article then details the longer genealogy of the lesbian bride in British and North American television drama, considering the ways in which gay and lesbian visibility is anchored within the figurative history of "the normal gay" (Warner 2000): Including a consideration of the ways in which the introduction of explicitly gay and lesbian characters might, paradoxically, undermine the feminist and queer history of Coronation

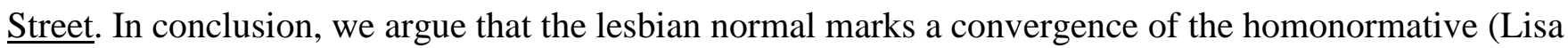
Duggan 2002) and the post-feminist which re-secures gender and class-based hierarchies and privileges. The lesbian normal is indicative of the emergence of what we term "post-queer popular culture", a social imaginary through which the socio-sexual freedoms of neoliberal citizenship --- such as the freedom to be an individual, the freedom to choose your sexual partner --- is extended to (some) queer subjects, but largely within the circumscribed terms of existing hetero-patriarchal gender roles.

\section{The Street}

First broadcast in 1960, Coronation Street is the world's longest-running soap opera. The iconic opening sequence establishes the setting of this drama, as the camera zooms across the rooftops of the eponymous terraced street in the fictional town of Weatherfield in North-West England. Coronation Street 
was attracting a staggering 20 million regular viewers within a few years of its first screening (Lez Cooke 2003). More than fifty years later, it is still one of the most popular programmes on UK television, currently airing three times a week, with an average audience of 9.5 million viewers per episode in the UK, and additional sizeable audiences in Australia, New Zealand and Canada. The impact of Coronation Street on British culture and society is significant; for example, it has launched the careers of generations of leading British scriptwriters and actors. It is commercially successful, garnering lucrative advertising and productlicensing agreements for the British media company ITV Granada.

Coronation Street was conceived during the British "new wave" (1956-1963) a movement of writers and film-makers which sought to both represent and legitimate working class cultures by making drama about working-class characters and communities (See John Hill 1986). As Lez Cooke notes, 'for workingclass audiences, especially in the Midlands and the North, who were watching television in huge numbers by the early 1960s, a programme like Coronation Street offered a shock of recognition' (Cooke 2003, 38). However, unlike the novels, plays and "kitchen sink" films that it drew upon stylistically and thematically, Coronation Street was never directly political in its intentions. Rather, it drew on longer histories of working class entertainment, such as music hall and comedy to produce character-driven, humorous, sentimental and, from the outset, nostalgic accounts of working class life. Marion Jordan (1981) named this hybrid of new wave social realism and melodrama "soap opera realism", and this hybrid became the model not only for soap opera, but for the reality genre television which dominates television schedules today. ${ }^{\mathrm{vi}}$ Unlike what has recently been dubbed "poverty porn" reality television, in which working class communities are objectified for entertainment (see Tracey Jensen 2014; Kim Allen, Imogen Tyler and Sara De Benedictis 2014; Tyler 2015), Coronation Street has long been distinguished by "strong and positive" depictions of working-class life. In particular, this "matriarchal soap" (Joanne Hollows 2000, 93), is notable for its outspoken, confident and independent working-class female characters, "social images" that were in 1960 --and remain today --- "conspicuous for their rarity on British television" (Richard Dyer 1981, 2). Since the 1990s, there has been a commercially oriented strategy to "freshen up" the Street through the inclusion of a 
more diverse cast of characters, including "gay couples, transsexual civil partnerships and [non-white] families" (Ezeogu 2013, and see Henderson 2007). Sophie and Sian's romance and wedding is precisely part of this "“freshen up' strategy", a headline-grabbing lesbian storyline which ostensibly aimed to "hook in" more elusive younger audiences.

\section{Sophie \& Sian}

The character of Sophie Webster has appeared in Coronation Street since her on screen "birth" in 1994 as the youngest daughter of Sally and Kevin Webster, characters since the 1980s. Sophie, portrayed by Brooke Vincent since 2004, is notable for being an active Christian. Sian Powers was introduced in 2009 as Sophie's fifteen-year-old school friend. In April 2010, the friends share a romantic kiss. Initially characterised as confused and unsure, the pair are shown deciding to explore their feelings and begin a relationship. The ensuing 'coming out' narrative encompasses an ensemble of characters of the Street, from Sian's aggressively homophobic father, to Sally Webster's struggles to accept her daughter --- “why can't she just be normal?" (Coronation Street, September 27, 2010). As tensions and prejudices are voiced and worked through, it is Rita Sullivan (Barbara Knox), a Coronation Street stalwart in the long tradition of strong female characters, who helps Sally comes to terms with her daughter's sexuality. In the dialogue between these two central characters, Rita guides the Street into a new era of sexual inclusion:

How wonderful, wonderful that you've brought her up so well she knows her own mind and what she wants from life, and bright enough to get her head round it. Not so easy for the likes of you and me though eh... isn't it great that this is 2010 and she hasn't got to hide anything, like she would have, when I was younger, and when you were younger' (Coronation Street, September 27, 2010).

Ultimately, the Street, comes to accept the couple and, in October 2011, Sophie proposes to her girlfriend Sian. This storyline brought to the screen the language and imagery of a lesbian romance; the everyday intimacies of a couple sharing a home, tying together families and communities. Although the 
character of Sian departed the soap soon after fleeing the church altar, this fictional couple, and images of their wedding day, continue to circulate online through a large fan following: from YouTube videos documenting every scene the couple shared, to fanfiction in which the couple are imagined reuniting.

\section{Marriage Equality in Britain}

As Charlotte Brunsdon notes, soaps are concerned with creating "moral consensus about the conduct of personal life. There is an endless unsettling, discussion and resettling of acceptable modes of behaviour within the sphere of personal relationships" (Charlotte Brunsdon 1981, 34, our emphasis). Indeed, soap operas are culturally significant precisely because they are part of the everyday lives of their audiences. As Dorothy Hobson writes:

They depict happenings and they also form part of cultural exchanges that go in both the home and the workplace. A large part of the enjoyment which is derived from watching soap operas is talking about them with other people. (Dorothy Hobson 2013, 150).

With millions of people discussing television drama storylines with family, friends and increasingly in the densely mediated context of the 21 st century, online social spaces, a lesbian wedding on prime-time television is a significant event in public understandings of shifting attitudes towards "marriage equality". In the fantasy world of Coronation Street, Sian and Sophie could get married in a church, in reality, at the time of broadcast, this would have been a legal impossibility in the UK. In 2011 a lesbian couple in Britain could enter into a legal partnership (since the Civil Partnership Act 2004), but could not be married, with the Marriage (Same-Sex Couples) Act 2013 only coming into force on 29 March, 2014. Thus, the 2011 spectacle of Coronation Street's lesbian wedding functions to shape the terms of the lesbian normal, both anticipating and actively crafting what a lesbian marriage might mean and look like, and it is hard to imagine a more conservative scene than this white church wedding. 
In the same year that Coronation Street aired its lesbian wedding, the British Prime Minister, David Cameron, declared his support for gay marriage. Cameron had begun his political life as a right-wing "profamily" conservative and had previously been a vocal supporter of the controversial "Section 28 ", legislation which ruled that local authorities "shall not intentionally promote homosexuality or publish material with the intention of promoting homosexuality" or "promote the teaching in any maintained [state funded] school of the acceptability of homosexuality as a pretended family relationship" (Section 28, 1988 amendment to the Local Government Act 1986). Responding to then Prime Minister Tony Blair's attempts to repeal Section 28 in 2003, Cameron accused him of being "anti-family" and voted against the (ultimately successful) quashing of this legislation. A decade later, as Conservative Prime Minister, Cameron and pro-marriage lesbian and gay activists found themselves unlikely political allies. In a speech at the Conservative Party Conference in October 2011, two months before the Coronation Street lesbian wedding was screened, Cameron clarified this u-turn, stating: "I don't support gay marriage despite being a Conservative. I support gay marriage because I'm a Conservative" (Cameron, 2011). In other words, for Cameron, the conservative values of marriage have now extended to include gay marriage. Homosexuality, which a decade previously he deemed a subversive threat to 'family values', is sanitised through the institution of marriage.

Lauren Berlant argues that the "logic of the national future" has relied on the generational form of the patriarchal family, with the ideal citizen imagined as a "straight, white, reproductively inclined heterosexual" (Berlant 1997, 18). Arguably, the legalisation of gay marriage has transformed this logic, as the fantasy of "the good life" is extended to include gay and lesbian citizens. Epitomized by the cultural spectacle of a lesbian white wedding, the lesbian normal functions as an imagined marker of a new era of social inclusion, "sealing the deal" on the incorporation of gender and sexual minorities within the institutional fabric of the state.

\section{The genealogy of the Lesbian Bride}


The roots of Coronation Street's lesbian wedding reside in the 1990s, a period in television history and wider popular culture when "polluting stereotypes" of homosexuals began to be replaced by "the normal gay" (Steven Seidman 2002, 14). ${ }^{\text {vii }}$ This shift, from “deviant" to "normal” was a response to a period of significant political backlash, exemplified in Britain by the rise of social authoritarian conservatism under the government of Margaret Thatcher (1979 to 1990). As Stuart Hall (Stuart Hall, 1988) argues, Thatcherism was characterised culturally by a moral agenda that saw "respectable working class families" pitted against “left-wing sexual deviants". The Presidency of Roland Reagan (1981 to 1989) saw a similar campaign waged against homosexuality, involving the intensive production of "national fantasies" of "normal intimacy": heterosexual, familial, marital, Christian, white and monogamous (Lauren Berlant 1997, 7).

The emergence of "The normal gay" has been interpreted by Warner (2000) as a reactive attempt to hold onto civil rights gains made by LGBT movements in the '70s and '80s, and an effort to ameliorate the political right-wing through claims to respectability and normalcy. Warner uses the example of James Collard, who became editor of the US magazine Out in 1998, and preceded to remove the words 'gay and lesbian' from the cover; declaring in a Newsweek article that he was "post-gay" (Warner 2000). Warner argues that Collard's "post-gay" is an attempt to dissociate "gay" and "lesbian" from "queer" creating a distance from the politics of queer activism, and staking a claim to belong within newly conservative public sphere (Warner 2000, 67). In terms of lesbian sexuality, what was actively reworked in this period was the association between lesbianism and femininity. While lesbianism had previously been associated with second-wave feminist rejection of oppressive forms of femininity, it was now reworked as a "chic" identity. In May 1993, the front cover of New York magazine featured a close up shot of Canadian singer-songwriter k.d.lang with the tag-line "Lesbian Chic: The Bold, Brave New World of Gay Women". Lesbianism began to be recoded through fashion, glamour and sexual provocation as a commercial, marketable identity category (Ann Ciasullo 2001). Through this trope, the idea of "the normal lesbian" emerged, and this began to be captured in British and US television drama from the early 1990s. 
In February 1991, American legal drama L.A. Law (1986-1994, NBC) featured the first kiss between two women on US commercial network television in the episode "He's A Crowd". viii In 1993, the Christmas episodes of UK Channel 4's Merseyside soap opera, Brookside, saw teenager Beth Jordache (Anna Friel) kiss her best friend, Margaret Clemence (Nicola Stephenson). Marking the first pre-watershed romantic kiss between two women on British TV, the Brookside kiss was widely reported in the press. Whilst this was a significant storyline, in this, and many other examples of "the lesbian kiss episode" in British and US television in this period, lesbianism is a temporary transgression, resolved through "heterosexual recuperation" (Clare Whatling 1997, 80). ${ }^{\text {ix }}$

In 1997 Ellen DeGeneres, described by Candace Moore as "arguably the woman whose performance of gayness has most saturated the public sphere" (Candace Moore 2008, 22), publicly 'came out'. Her sitcom Ellen (1994-1998, ABC) centred on the life of Ellen Morgan, an LA bookstore owner, played by DeGeneres. The televisual coming out of Morgan in "The Puppy Episode" (April 30, 1997) was "one of the most watched (42 million viewers) and talked about episodes in American television history" (Didi Herman 2003, 9). This episode was preceded by DeGeneres' declaration on the cover of Time magazine: "Yep, I'm Gay". The Time magazine cover's carefully coded image of DeGeneres as a relaxed, happy, unthreatening, allAmerican, white, middle-class citizen illustrates the politics of the normal gay (see Bonnie Dow 2001). As Warner notes "those whose sex is least threatening, along with those whose gender profiles are least queer, are put forward as the acceptable face of [the gay rights] movement" (Warner 2000, 66). Nonetheless, after the initial furore of Ellen's double coming-out event, ratings dropped and Ellen was cancelled (Dow 2001; Jennifer Reed 2005). While DeGeneres would later return to successfully claim a role as a US talk-show host, in the 1990s lesbian subjectivity seemed impossible to sustain in television drama. As Anna McCarthy argues, "although the network could support queer television as a spectacular media event, it could not sanction a lesbian invasion of serial television's more modest form of history making, the regularly scheduled weeks of televisual flow" (Anna McCarthy 2001, 597). However, as Bonnie Dow discusses in her periodisation of gay and lesbian representation in US television history, there are rarely any "incidental" gay 
or lesbian characters in this period. Within television drama, lesbian sexuality is still largely imagined as "a problem" to be resolved through the storyline. Further, the dramatic arc of the lesbian storyline, from confession to acceptance, is framed in terms of the impact of "the problem" on heterosexual families, friends and communities.

In the mid-2000s "the diversity and breadth of gay characters on television" dramatically increased (Alice Marwick, Mary L. Gray and Mike Ananny 2014, 630). In 2010 media advocacy organisation GLAAD $^{\mathrm{x}}$ issued their $15^{\text {th }}$ annual television report, declaring a "record season for inclusivity" on US television (Matt Kane 2010). In the summer of 2013 the online entertainment website $\underline{\text { vulture }}^{x i}$ claimed that $^{2}$ "Lesbians are Having the Best Summer Ever on TV" (Margaret Lyons 2013). Long running dramas introduced lesbian characters and storylines and new programmes featured central lesbian and bisexual characters. As Suzanna Danuta Walters notes, many consider this visibility as "a sign of substantive gay progress" (Suzanna Danuta Walters 2014, 2). Arguably, however, these are dramas still played out for an imagined heterosexual gaze, as Dow puts it, gay and lesbian storylines "are about being gay" (Dow 2001, 138). The now generic conventions of the lesbian normal are evident in Coronation Street's introduction of its first lesbian romance in 2010. When Sophie comes out, her mother, Sally Webster responds: “If I could wave a magic wand right now and make you normal, I'm telling you I'd do it, but I can't, so I'm just going to have to wait for the shock to wear off, and in time I'll get used to a different sort of normal" (Coronation

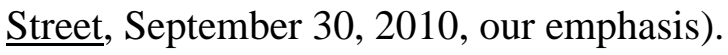

\section{Straightening out the lesbians}

In a promotional shoot for the Coronation Street lesbian wedding episodes in British gossip magazine Heat, Vincent and Parkinson pose as bunny girls, in pink corseted underwear, bunny ears and high heeled shoes. The subheading of the accompanying article reads, "Corrie's Sophie and Sian kissed a girl, but did they like it? Paul Flynn finds out": playing with the lyrics of the 2008 Katy Perry pop hit. Heat's headline 
"we sent each other valentine's cards", the inclusion of the name of the male journalist, and his investigative role, frames the Coronation Street lesbian romance in terms of the titillation of "lesbianism as a performance" for a heterosexual male gaze. ${ }^{\text {xii }}$ Circulating across multiple media platforms, these kinds of promotional campaigns for lesbian storylines are normally accompanied with the reassuring caveat that the actress playing the lesbian character is “straight in real life". As Coronation Street's Brooke Vincent told gossip magazine Reveal magazine in 2011, “I want men to know I'm not gay”. In promotional materials such as this, the prime-time televisual lesbian occupies the post-feminist positionality which Gill describes as 'the midriffs': the "active, desiring, sexual subjects who choose to present themselves in a seemingly objectified manner because it suits their (implicitly liberated) interests to do so" (Gill 2009, 148). Indeed, one of the key effects of mainstream television's attempts to diversify (and expand audience share), through the scripting of lesbian characters and storylines, is that it has become increasingly "straight" with regard to the prevailing gendered norms of femininity.

Warner notes that "the point of being normal is to blend, to have no visible difference and no conflict" (Warner 2000,60). Certainly, in terms of gender norms lesbian characters on mainstream television

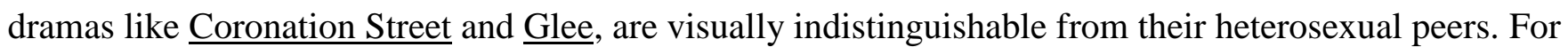
example, Sophie and Sian are coded through a youthful, white, 'everyday' femininity, integrated into the visual conventions of the soap opera. Indeed, this absence of difference is a defining feature of the lesbian normal. Take the June 2012 cover of The New Yorker magazine, which announced the imminent arrival of national marriage equality with an insipid watercolour titled "June Brides" (Gayle Kabaker). This painting depicted two brides in full length bridal gowns and veils, clasping a shared bouquet of red roses which matches the red lipstick on otherwise featureless faces. The loose figurative style of this painting rendered these brides not only indistinguishable from each other, but also from previous "June Bride" magazine covers from across the previous century, published to celebrate a tradition of spring marriage. Arguably, the absence of 'visible difference' can operate in disruptive ways. The lesbian normal might be read as a rejection of clichéd assumptions about lesbians that refuses the stigma of heterosexism. However, the lesbian 
is made normal through a rejection, a silencing, of this longer antagonistic relationship between lesbians, feminism and femininity. As Alison Rooke notes on this history:

The lesbian body politic has significantly changed since the 1980s and 1990s. The lesbian feminist critique of "patriarchy" was born out through embodied practices. The lesbian feminist body was unruly, questioning the discourses of appropriate femininity by sprouting hair, changing shape, refusing constraining clothes, and so on. Lesbian feminist culture offered the opportunity to experiment and explore dominant conceptions of gender; it offered a space to rethink heteronormativity and for some the possibility to live, at least temporarily in space and time, outside of its bounds (Alison Rooke 2007, 247, see also Judith Roof 1991)

In particular, the feminisation of the lesbian body involves the abjection of the butch, and the disappearance of the butch/femme couple (see Daniel Farr and Nathalie Degroult 2008). The history of the butch is a predominantly working class history, one that evokes the "usurping of male privilege" through the "assertion of women's sexual autonomy" (Elizabeth Lapovsky Kennedy and Madeline D. Davis 1992, 77). ${ }^{\text {xiii }}$ It is notable then, that even the working class lesbians of Coronation Street retain no hints of this butch legacy. As Jack Halberstam notes:

the butch... gets cast as anachronistic, as the failure of femininity, as an earlier, melancholic model of queerness that has now been updated and transformed into desirable womanhood, desirable, that is, in a hetero-visual model. But the butch lesbian is a failure not only in contemporary queer renderings of desire; she stands in for failure in consumer culture writ large because her masculinity becomes a block to heteronormative male desire. (Jack Halberstam 2011, 95)

In respect of the femme lesbians of the lesbian normal, the butch is too queer to be subsumed within increasingly hegemonic gender norms of mainstream lesbian sexuality. ${ }^{\text {xiv }}$ As a consequence, the butch has either disappeared, or at best takes on a minor, supporting role within dramas that feature the femme-femme 
couples characteristic of the lesbian normal. Butch is "blotted out to provide a free channel for commodification" (Halberstam 2011, 95).

\section{'Queer Street' ${ }^{\mathrm{xv}}$}

Despite a notable historical absence of gay and lesbian characters and storylines, Coronation Street has a rich, queer cultural history. Coronation Street creator and long-time scriptwriter Tony Warren died while we were writing this article and many of the subsequent reflections on his career noted his accounts of homophobic culture within television that, as an openly gay man, he actively and consciously wrote against. Indeed, many of Coronation Street's working class soap-queens are gay icons in Britain: From 'Tart with a heart' Elsie Tanner (Patricia Phoenix) (The Independent, 1999) to barmaid come publican Bet Lynch (Julie Goodyear), characters long celebrated for their strength, independence, overt sexuality and camp femininity: "Bet dresses like a drag queen and drag queens have often returned the compliment" (Susan Irvine, 1995). Reflecting on this rich history of divas and matriarchs, Tony Warren revealed that he drew on the voices of “queens" he met in Manchester's gay village when writing lines for female characters (Dianne Bourne, 2007; Daniel Kilkenny, 2016). The 2007 “Queer Corrie”, event at the Queer Up North Arts Festival, featured a specially edited historical showcase of "queer moments" from the soap. This queer legacy extends far beyond the soap itself, consider, for example, rock group Queen's anthem "I Want to Break Free" (1983) known for its music video featuring the band dressed as female characters from Coronation Street.

In order to understand the queer history of Coronation Street, it is important to note that femininity, and in particular heterosexual female respectability, has never been easily accessible to non-white or working-class women (Beverley Skeggs, 2004, Rooke, 2007). As Carole Anne Tyler observes, “[A] real woman is a real lady; otherwise, she is a female impersonator, whose 'unnaturally bad' taste --- like that attributed to working-class women or women of colour --- marks the impersonation of such" (Tyler, 2002, 61, see also Skeggs 2001). The failure of working-class women to "do femininity" correctly is the subject of much malicious television comedy, including the insistent pathologising of working-class femininities 
within reality television. However, Coronation Street scriptwriters such as Warren arguably worked with this 'failure', celebrating the ways in which its working-class female characters queer respectable femininities through class. As one journalist admiringly described Bet Lynch in 1995 "Picture a warrior-woman in breastplate of leopard print and Lycra. She's all biceps and bosoms and defiant sexuality but with a sharp line in dry put-downs that keeps men in their place" (Irvine, 1995). Characters like Bet Lynch were clever, witty, strong, independent and sexually confident. They communicated a "knowing subversion" of respectability, and are seen to take pleasure in their gendered and classed performances. As Coronation Street scriptwriter and playwright Jonathan Harvey ${ }^{\mathrm{xvi}}$ notes about his hit stage play, Corrie! (2000): Coronation Street is "camp with an edge. If someone's wearing a leopard-skin glove, there's an iron first inside. Just this morning, I was telling the actor who plays Bet in Corrie! to butch it up..." (Lee 2010, our emphasis).

It is notable that as the lesbian normal reached its climax on Sophie and Sian's wedding day, the queer pleasure of the drama lay not at the altar but in Mary Taylor's (Patti Clare) teasing comment to street matriarchs Rita Sullivan (Barbara Knox) and Emily Bishop (Eileen Derbyshire), that the two of them would "make a lovely couple" and "could be mistaken for lesbians" as they leave the corner shop in their finery to attend the wedding. It is in these small asides, that queer subtexts disturb the hegemony of post-queer popular culture.

\section{Homonationalism}

Coronation Street was celebrated in the spectacular opening ceremony British director Danny Boyle and scriptwriter Frank Cottrell Boyce devised for the London Olympics in 2012. Boyle and Cottrell Boyce, a former Coronation Street scriptwriter, also screened a compilation of famous kisses from British film and television in which the iconic lesbian kiss from the soap opera Brookside was celebrated as a pivotal moment in British media history and a symbol of national pride. This was a significant inclusion at the Olympic opening ceremony, not only for its acknowledgement of the impact of this taboo-breaking 
Brookside episode, but because it was the first gay kiss to be broadcast in many nations, "including 76 countries where homosexuality is illegal" (The Gay UK, 2012). The London Olympics was the "biggest national television event since current measuring systems began" (BBC Media Centre, 2012), and the opening ceremony was watched by an estimated 900 million people in 220 territories around the world (Associated Press, 2012). The spectacular multi-media opening ceremony not only celebrated sexual equality, but also paid homage to the significance of feminist and class struggles through its theatrical restaging of Britain's history, with performance sequences that referred to the suffragettes, trade-unionism and the National Health Service (NHS). What was displayed through this ceremony was a globally visible national fantasy of Britain as an exemplary feminist and 'gay-friendly' liberal democracy.

Jasbir Puar employs the concept of "homonationalism" as 'an analytic category' to "understand and historicize" precisely "how and why a nation's status as 'gay-friendly"' is politically desirable in the context of global corporate capitalism and supporting forms of international relations (Jasbir Puar 2013, 336). As Puar argues, sovereign states in the global north (and their corporate partners) embrace particular kinds of "sexually progressive multiculturalism" as a means of legitimating warfare, occupation, oppressive border controls and the expropriation of resources $(2013,337)$. Sara Farris draws upon and develops Puar's work in her account of "femonationalism", which examines the ways in which the civic and human rights of girls and women, are increasingly instrumentalized to legitimate punitive controls against the imagined Muslim threat to European traditions of liberal democracy. As Farris writes, "the proclaimed defence of women constitutes a common denominator of the so-called new radical Right in Europe, as well as an insidious argument increasingly deployed by neoliberal governments and the mass media across the continent" (Sara Farris 2012, 184). For example, Western opposition to the oppression of women and LGBT people in Afghanistan was corralled as a political justification for the 'War on Terror'. Gender equality and tolerance of queer citizens thus form an integral part of the contemporary post-feminist, post-queer cultural political economy. ${ }^{\text {xvii }}$ This cultural political economy extends from seemingly banal television drama though to the surveillance of "un-modern" populations in "enemy regimes" (see also Jin Haritaworn, Adi Kunstman and 
Silvia Posocco 2014). Whilst we can't do justice to this critical literature here, we want to make the link between the crafting of liberal values of queer tolerance, evident within the banality of the lesbian normal, and the deployment of homonationalism to legitimate violence against 'enemies of the state'. The lesbian normal, and other instantiations of queer tolerance, are exported globally through television, newspapers, films, magazines and websites, to legitimate the political and economic strategies of global corporate capitalism. Sexual democracy is presented as life-style choice, denuded of the political, economic, cultural and religious struggles that shape sexual subjectivities on the ground, and the stigma and violence that accompanies the wrong "sexual choices" in different local and geo-political contexts.

\section{Conclusion: Post-Queer Popular Culture}

This article has been concerned with mapping and critically interrogating the emergence of the lesbian normal. Drawing on feminist accounts of the politics of post-feminist media culture we have drawn attention to the limits of this post-queer sensibility. We have detailed how the lesbian who is being 'brought out of the closet' into the glare of popular culture, is very often the lesbian of hetero-masculine soft-porn fantasies. This young girly normal lesbian is a figure made possible by the unknotting of historical ties between lesbianism and feminist politics. Through the abjection of unruly and especially butch lesbian body politics, the lesbian normal occludes queer commitments to anti-normativity. Indeed, the lesbian normal exemplifies "homonormativity": "a politics that does not contest dominant heteronormative assumptions and institutions, but upholds and sustains them" (Duggan 2002, 179). So whilst figures of the lesbian normal might be crafted with liberal intentions it is our argument that this figure is indicative of the defanging of feminist and queer politics.

Despite the pessimism of this central argument, we want to conclude by emphasising the pleasures of post-queer popular culture. The rich, queer history of Coronation Street is evidence of the ways in which mainstream culture is continually mined, appropriated and reworked by the queer interpretive strategies of audiences. So whilst this figurative account has largely been concerned with disentangling the figure of the 
lesbian bride in mainstream television, our future research explores more liminal television dramas and queer fan-fiction (see Kate McNicholas Smith forthcoming). If the lesbian bride draws her femme affectivity from the conservative gender politics of white bridal culture, the reworking of the lesbian normal within fan-based media production is evidence of the productive contradictions of post-queer popular culture. It is within the queer aesthetics of fan cultures that we find the more "promising monsters" of the lesbian normal (Donna Haraway 2004).

Acknowledgements: Thanks to Celia Roberts, who contributed to the development of original discussions on this topic, and to Bruce Bennett, Tracey Jensen, Ece Kocabıçak, Gail Crowther and the anonymous reviewers for their valuable feedback on drafts of this article. Imogen Tyler acknowledges the support of the Leverhulme Trust through a Philip Leverhulme Prize. 


\section{Bibliography}

Allen, Kim, Imogen Tyler and Sara De Benedictis. 2014. “Thinking with 'White Dee': The Gender Politics of 'Austerity Porn"'. Sociological Research Online. 19 (3).

Associated Press. 2012. "London 2012 opening ceremony audience hit 900 million predicts IOC" The Independent. [Online] August 7, 2012. [Accessed June 3, 2012]. Available from:

http://www.independent.co.uk/sport/olympics/news/london-2012-opening-ceremony-audience-hit900-million-predicts-ioc-8015361.html

Ball, Vicky. 2012. "The "feminization" of British Television and the Re-Traditionalization of Gender". Feminist Media Studies 12 (2): 248-264.

Berlant, Lauren. 1997. The Queen of America Goes to Washington City: Essays on Sex and Citizenship. Durham \& London: Duke University Press.

Bourne, Dianne. 2007. “Corrie Creator's Jail Fear”. Manchester Evening News. May 11 2007. [Online] [Accessed March 3, 2016]. Available from: http://www.manchestereveningnews.co.uk/news/greatermanchester-news/corrie-creators-jail-fear-991884

Bride Wars. 2009. Film Directed by Gary Winick. USA: $20^{\text {th }}$ Century Fox.

Brookside. Television Series. 1982-2003. UK: Channel 4.

Brunsdon, Charlotte. 1981. "Crossroads: Notes on a Soap Opera”. Screen. 22 (4): 32-37.

Brunsdon, Charlotte. 1997. Screen tastes: soap opera to satellite dishes. London: Routledge.

Brunsdon, Charlotte. 2000. The Feminist, the housewife, and the soap opera. Oxford: Clarendon Press.

Buckingham, David. 1987. Public Secrets: "Eastenders" and Its Audience. London: BFI Publishing.

Butler, Judith. 1993. "Imitation and Gender Subordination". In The Lesbian and Gay Studies Reader. Edited by Henry Abelove, Michele Aina Barale and David M Halperin. New York: Routledge. 307-320.

Cameron, David. 2011. 'Leadership for a better Britain'. [Online]. 5 October 2011, Conservative Party Conference, Manchester. [Accessed January 2012]. Available from:

http://www.conservatives.com/News/Speeches/2011/10/David_Cameron_Leadership_for_a_better_Bri tain.aspx

Ciasullo, Ann M. 2001. "Making Her (In)Visible: Cultural Representations of Lesbianism and the Lesbian Body in the 1990s." Feminist Studies 27 (3): 577-608.

Cooke, Lez. 2003. British Television Drama: A History. London: BFI Publishing.

Coronation Street. 1960-. Television Series. UK: ITV.

Coronation Street. 2011. Television Series, episode. UK: ITV. 27 September 2010.

Coronation Street. 2011. Television Series, episode. UK: ITV. 30 September 2010.

Coronation Street. 2011. Television Series, episode. UK: ITV. 29 December 2011.

Couldry, Nick. 2000. The place of media power: pilgrims and witnesses of the media age. London: Routledge.

Dow, Bonnie. 2001. "Ellen, Television, and the Politics of Gay and Lesbian Visibility." Critical Studies in Media Communication 18 (2): 123-140.

Duggan, Lisa. 2002. 'The New Homonormativity: The Sexual Politics of Neoliberalism'. In Materializing Democracy: Toward a Revitalized Cultural Politics, edited by Russ Castronovo and Dana D. Nelson. Durham \& London: Duke University Press. 175-94.

Dunham, Lena (2012) “The bride in her head". The New Yorker. July 10. [Online] [Accessed January 2016] Available from: http://www.newyorker.com/culture/cultural-comment/the-bride-in-her-head

Dyer, Richard, ed. 1981. Coronation Street (Television Monograph, 13). London: BFI Publishing.

Elizabeth Freeman. 2002. The Wedding Complex: Forms of Belonging in Modern American Culture. Durham, N.C.: Duke University Press. 
Ezeogu, Jessica. 2013. “Coronation Street Appeal” Slideshare. [Online] [Accessed January 2016] Available from: http://www.slideshare.net/Jerasica_99/coronation-street-appeal

Farr, Daniel, and Nathalie Degroult. 2008. "Understand the Queer World of the L-Esbian Body: Using Queer as Folk and The L Word to Address the Construction of the Lesbian Body." Journal of Lesbian Studies 12 (4): 423-434.

Farris, Sara R. 2012. "Femonationalism and the "Regular" Army of Labor Called Migrant Women". History of the Present. 2 (2) 184-199.

Frey-Vor, Gerlinde. 1991. Coronation Street: infinite drama and British reality: an analysis of soap opera as narrative and dramatic continuum. Trier: WVT Wissenschaftlicher Verlag Trier.

Geraghty, Christine. 1991. Women and soap opera: a study of prime time soaps. Cambridge: Polity Press.

Gill, Rosalind, and Elena Herdieckerhoff. 2006. "Rewriting the Romance: New Femininities in Chick Lit?" Feminist Media Studies 6 (4): 487-504.

Gill, Rosalind. 2009. 'Beyond the "Sexualization of Culture" Thesis: An Intersectional Analysis of

"Sixpacks", "Midriffs" and "Hot Lesbians" in Advertising'. Sexualities. 12 (2): 137-160.

Gill, Rosalind. 2016. "Postfeminism and the new cultural life of feminism". Diffractions. 6: 1-8.

Glee. 2009-2015. Television Series. Seasons 1-5. USA: Fox.

Halberstam, Jack. 2011. The Queer Art of Failure. Durham \& London: Duke University Press.

Hall, Stuart. 1988. The Hard Road to Renewal: Thatcherism and the Crisis of the Left. London: Verso.

Haraway, Donna. 2004. "Cyborgs, Coyotes and Dogs: A Kinship of Feminist Figurations." In The Haraway Reader, 321-342. London \& New York: Routledge.

Haritaworn, Jin, Kunstman, Adi, \& Posocco, Silvia, eds. 2014. Queer Necropolitics. Oxon: Routledge.

Henderson, Lesley. 2007. Social Issues in Television Fiction. Edinburgh: Edinburgh University Press.

Herman, Didi. 2003. “'Bad Girls Changed My Life': Homonormativity in a Women's Prison Drama.” Critical Studies in Media Communication 20 (2): 141-159.

Hickling, Alfred. 2010. "Jonathan Harvey: 'I've given up seeking approval'”. The Guardian. April 272010.

[Online] [Accessed 3 March 2016] Available from:

$\mathrm{http}: / / \mathrm{www}$. theguardian.com/stage/2010/apr/27/jonathan-harvey-canaries.

Hill, John. 1986. Sex, Class and Realism: British Cinema 1956-1963. London: BFI Publishing.

Hobson, Dorothy. 2003. Soap opera. Cambridge: Polity Press

Hobson, Dorothy. 2013. "Soap Operas at Work" in Remote control: television, audiences, and cultural power. Edited by Ellen Seiter, Hans Borchers, Gabriele Kreutzner, and Eva-Maria Warth. First published 1989. London; New York. 50-167.

Hollows, Joanne. 2000. Feminism, Femininity and Popular Culture. Manchester: Manchester University Press.

http://www.telegraph.co.uk/culture/theatre/theatre-features/7924819/Corrie-on-stage-hairnets-to-gaykisses.html

Ingraham, Chrys. 1999. White Weddings. New York: Routledge.

Irvine, Susan. 1995. "Buxom, but no bimbo. Profile: Bet Lynch". The Independent. September 221995. .

[Online] [Accessed March 3, 2016]. Available from: http://www.independent.co.uk/life-style/buxombut-no-bimbo-1602489.html

Jensen, Tracey. 2014. "Welfare Commonsense, Poverty Porn and Doxosophy". Sociological Research Online. 19 (3).

Jordan, Marion. 1981. "Realism and Convention". In Coronation Street (Television Monograph, 13). Edited by Richard Dyer. London: BFI Publishing. 27-39

Kane, Matt. 2010. “GLAAD's 15th Annual Where We Are on TV Report Reveals a Record High for LGBT Characters, but Faltering Diversity Stats on Broadcast Networks." GLAAD. Available from: http://www.glaad.org/2010/09/29/glaads-15th-annual-where-we-are-on-tv-report-reveals-a-recordhigh-for-lgbt-characters-but-faltering-diversity-stats-on-broadcast-networks.

Kilkelly, Daniel. 2016. “Tony Warren 1936-2016: 6 Ways Coronation Street's Trailblazing Creator Changed The Face Of British TV”. Digital Spy. March 2 2016. [Online] [Accessed March 3, 2016]. Available 
from: http://www.digitalspy.com/soaps/coronation-street/feature/a785464/tony-warren-1936-2016-6ways-coronation-streets-trailblazing-creator-changed-the-face-of-british-tv/

L.A. Law. 1991. Television Series, episode. 'He’s A Crowd'. S5, Ep12. USA: NBC. 7 February 1991.

Lapovsky Kennedy, Elizabeth and Madeline D. Davis. 1992. Boots of Leather, Slippers of Gold: The

History of a Lesbian Community. New York: Routledge.

Lee, Veronica. 2010. "Corrie on stage: hairnets to gay kisses". The Telegraph. August 3 2010. [Online]

[Accessed March 4, 2016]. Available from:

Livingstone, Sonia M. 1998. Making sense of television: the psychology of audience interaction (2nd ed).

London: Routledge.

Lovell, Terry. 1990. "Landscapes and stories in 1960's British realism” Screen. 37(4 ): 357-376.

Lyons, Margaret. 2013. "Lesbians Are Having the Best Summer Ever on TV". July 25, 2013. Vulture.

[Online]. [Accessed 30 July 2013]. Available from: http://www.vulture.com/2013/07/lesbians-arehaving-the-best-summer-ever-on-tv.html.

Marshall, Daniel. 2016. "Reading queer television: Some notes on method". Review of Education, Pedagogy, and Cultural Studies 28 (1): 85-101

Marwick, Alice, Mary L. Gray, and Mike Ananny. 2014. “'Dolphins Are Just Gay Sharks': Glee and the Queer Case of Transmedia as Text and Object". Television \& New Media. 15(7): 627-647.

McCarthy, Anna. 2001. “Ellen: Making Queer Television History.” GLQ: A Journal of Lesbian and Gay Studies 7 (4): 593-620.

McRobbie, Angela. 2004. "Post-Feminism and Popular Culture." Feminist Media Studies 4 (3): 255-264.

Montalbano, Lori. 2013. 'To Glee or Not to Glee: Exploring the Empowering Voice of the Glee Movement'.

In Queer Media Images: LGBT Perspectives, edited by Theresa Carilli and Jane Campbell. Plymouth:

Lexington Books. 55-64.

Moore, Candace. 2008. "Resisting, Reiterating and Dancing Through: The Swinging Closet Doors of Ellen

DeGeneres's Televised Personalities." In Televising Queer Women: A Reader, edited by Rebecca

Beirne, 17-32. New York: Palgrave Macmillon.

Orange is the New Black. 2013-. Television Series. Seasons 1-3. USA: Netflix

Pride and Prejudice. 1995. Television Series. UK: BBC.

Puar, Jasbir. 2013. "Rethinking Homonationalism” International Journal of Middle East Studies. 45.(2): 336339.

Reed, Jennifer. 2005. 'Ellen Degeneres: Public Lesbian Number One'. Feminist Media Studies. 5 (1): 23-36.

Roof, Judith. 1991. A lure of knowledge: Lesbian sexuality and theory. New York: Columbia University Press.

Rooke, Alison. 2007. "Navigating Embodied Lesbian Cultural Space: Toward a Lesbian Habitus". Space and Culture. 10 (2): 231-252.

Seidman, Steven. 2002. Beyond the Closet: The Transformation of Gay and Lesbian Life. New York: Routledge.

Sense8. 2015-. Television Series. Season 1. USA: Netflix

Skeggs, Beverley. 2001. “The Toilet Paper: Femininity, Class and Misrecognition”. Women's Studies International Forum. 24 (2-3): 295-307.

Skeggs, Beverley. 2004. Class, self and culture. London: Routledge

Smith, Anna Marie. 2015. "Orange is the Same White". New Political Science. 37 (2).

Sum N-L. and Jessop B. 2013. Towards a cultural political economy: putting culture in its place in political economy. Cheltenham: Edward Elgar.

The Gay UK. 2012. "Same Sex Kiss Seen Across the World". July 30. [Online] [Accessed 10 August 2015] Available from: http://www.thegayuk.com/magazine/4574334751/SAME-SEX-KISS-SEEN-

ACROSS-THE-WORLD/3093963

The Independent. 1999. "Accidental Heroes of the 20th Century - 31: Elsie Tanner, soap opera heroine". March 13, 1999. [Online] [Accessed March 3, 2016]. Available from:

http://www.independent.co.uk/arts-entertainment/accidental-heroes-of-the-20th-century-31-elsietanner-soap-opera-heroine-1080127.html 
Tropiano, Stephen. 2002. The Prime Time Closet: A History of Gays and Lesbians on TV. New York: Applause Theatre and Cinema.

Tyler, Carol-Anne (2002) Female Impersonation. New York: Routledge.

Tyler, Imogen. 2015. "Classificatory struggles: class, culture and inequality in neoliberal times". The Sociological Review. 63 (2): 493-511.

Viner, Brian. 1995. "Queer Street”. Mail On Sunday. June 25 1995. 21,24-25.

Walters, Suzanna Danuta. 2014. The Tolerance Trap. New York: New York University Press.

Warner, Michael 2000. The Trouble With Normal: Sex, Politics, and the Ethics of Queer Life. Cambridge: Harvard University Press.

Welsh, Kaite (2015) "Now it's OK to be a lesbian --- so long as you're hot and white" The Telegraph. October 19. [Online] [Accessed 10 November 2015] Available from: http://www.telegraph.co.uk/women/womens-life/11940810/Lesbian-celebrities-Gay-is-now-ok-solong-as-youre-hot-and-white.html

Whatling, Clare. 1997. Screen Dreams: Fantasising Lesbians in Film. Manchester: Manchester University Press.

Winch, Alison. 2012. "We Can Have It All' The Girlfriend Flick". Feminist Media Studies 12 (1): 69-82. 


\section{Figures}

Figure 1. Sophie \& Sian's Wedding Day (Coronation Street, December 29 2011, reproduced with permission) (Copyright: Rex Features) 


\section{Author Bios}

Kate McNicholas Smith is a lecturer in Gender, Media and Cultural Studies at Lancaster University, UK.

Kate's research is primarily concerned with gender, sexuality and popular culture. Current research focuses on LGBT visibility, in particular the changing representations of lesbian characters on television and in wider media culture. She is particularly interested in new media platforms and there utilisation by audiences in dynamic, resistant and creative ways. Email: k.mcnicholassmith1@lancaster.ac.uk

Imogen Tyler is a Professor of Sociology at Lancaster University. She has published widely on social class, gender, inequalities, migrancy, borders, neoliberalism and forms of political resistance. Recent publications include Revolting Subjects: Social Abjection and Resistance in Neoliberal Britain and Immigration Protest: Politics, Aesthetics and Everyday Dissent (co-edited with Katarzyna Marciniak). She is currently funded by the Leverhulme Trust and is writing a new book, provisionally entitled Stigma Nation. This article draws on her current research interests in stigma, normativity and neoliberalism. Email: $\underline{\text { i.tyler@ lancaster.ac.uk }}$ 
${ }^{\mathrm{i}}$ The iconic Canal Street is located at the centre of the area known as the 'gay village' in the city of Manchester in the North West of England, an area of (predominantly) clubs and bars that has become a recognisable centre of LGBT community and representation (appearing most famously as the setting for Russell T Davis' Queer as Folk, 1999-2000).

${ }^{\text {ii }}$ Coronation Street introduced a transsexual character, Hayley Cropper (Julie Hesmondhalgh), in 1998, but waited until 2003 to depict a gay (male) kiss.

${ }^{\text {iii }}$ We have chosen to focus here on the appearance of lesbian characters within mainstream 'family viewing' television dramas, as we are precisely interested in unpicking the naturalization of lesbian romance, and the gendered norms and conventions through which this ordinariness has been effected. See also Rob Cover, 2000 , for a discussion on the importance of studying mainstream media representations of non-heterosexual relationships. It is also important to note the extent to which more seemingly subversive representations of lesbian romance, such as those in US prison drama Orange is the New Black, reproduce what Anne Marie Smith terms a white gaze, 'that often has a male heterosexual structure' (Anne Marie Smith 2014).

iv The final 2015 season of Glee featured the wedding of Santana Lopez (Naya Rivera) and Brittany S. Peirce (Heather Morris). As Glee broadcast its lesbian wedding, same-sex marriage had been made legal in thirtyseven US states. On June 26, 2015, the United States legalized same-sex marriage nationwide, when the Supreme Court ruled state level bans unconstitutional.

${ }^{v}$ Since the publication of the key post-feminist literature a decade ago, there has been resurgence in feminist politics, both via celebrity "feminist" figures, and through well-publicised activism, campaigns and movements. As Gill describes, "one way of reading this 'new cultural life of feminism' has been to suggest that critical notions like postfeminism may no longer hold force or have analytical purchase for this changed context' (Gill 2016, 1). Part of what we interested in examining in this article is precisely the continued purchase of post-feminism. As Gill reminds us, "new cultural trends do not simply displace older or existing ones"; critical work in this area "[needs] to be attentive to both continuity and change" (Gill 2016, 2).

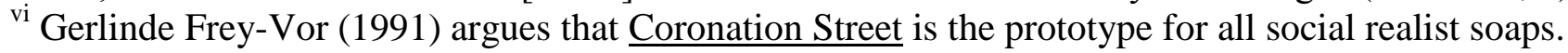
Unsurprisingly, given its centrality in British television history and wider popular culture, Coronation Street has been the subject of scholarly and critical interest, including audience research (Livingstone 1998), fan research (Couldry 2000), television production (Buckingham 1987) and studies on "women's genre" television (Lovell 1990; Brundson 1997, 2000; Geraghty 1991; Hobson 2003).

${ }^{v i i}$ At the same time, in the UK television adaptions of Jeanette Winterson's Oranges are Not the Only Fruit (1991, BBC) and Armistead Maupin's Tales of the City (1993-4, Channel 4 and PBS) alongside Queer as Folk (1999-2000, Channel 4) witnessed the broadcast of more politicized representations of queer lives into mainstream culture.

viii Whilst one of the characters, C.J Lamb (Amanda Donohoe), described her sexuality as "flexible" (Tropiano 2002, 89), a lesbian relationship never developed and the following series saw her in a relationship with a man. The other character, Abby Perkins (Michele Green), quickly reiterated her heterosexuality before being written out of the drama.

ix Beth's subsequent relationship with her college lecturer, Chris Myers (Marie Francis), ended in July 1994, and the following year saw her on trial for the murder of her father before her eventual death in prison.

Margaret Clemence exited in April 2014 with the character leaving to join her ex-boyfriend in Bosnia; a man she describes as "the only person I've ever really loved" (Brookside, 1994).

${ }^{x}$ A US based lesbian gay, bisexual and transgender media advocacy organisation, originally formed in 1985 as the Gay and Lesbian Alliance Against Defamation (GLAAD).

${ }^{x i}$ Online entertainment site for New York magazine.

${ }^{\text {xii }}$ Whilst the majority of Coronation Street's regular audience are women (Ezeogu, 2013), these images repeat and circulate through multiple media sites, repeatedly published in newspapers, magazines, websites and on social media. 
xiii As Elizabeth Lapovsky Kennedy \& Madeline Davis describe in their research with butch-fem communities in 1930s-60s Buffalo, New York, 'butch-fem roles ... were working-class lesbians only means of expressing resistance to the heterosexual world in this prepolitical era of gay and lesbian history' (Lapovsky Kennedy \& Davis 1992, 62).

${ }^{\text {xiv }}$ Ellen DeGeneres, her short hair and clothing connoting a soft butch figure, is, in a sense, an exception in the visual landscape of the lesbian normal. In recent years, DeGeneres has regained her popularity, mobilising a complex (and carefully managed) convergence of the queer and the conservative in mainstream popular culture (see Moore, 2008; McCarthy, 2001; Dow, 2005; Reed, 2005). However, the tensions of this convergence recall Halberstam's account of the possibility of '[occupying] the role of the butch while evacuating it at the same time' (Halberstam 2011, 96).

${ }^{\mathrm{xv}}$ In a 1995 article in the Mail on Sunday, titled "Queer Street", journalist Brian Viner discussed the longstanding appeal of Coronation Street to gay audiences (Viner, 1995)

${ }^{x v i}$ Harvey has written 226 episodes of Coronation Street since 2010, including the $29^{\text {th }}$ December 2011 lesbian bride episode. He developed the first openly gay storyline in 2004 which he described as "the chance to put gay relationships into 8 million living rooms" (Hickling, 2010)

${ }^{x v i i}$ See Sum N-L. and Jessop B (2013) and Jensen and Tyler (2015) for a definition of cultural political economy 